\title{
IDENTIFYING THE BEST DECENTRALIZED RENEWABLE ENERGY SYSTEM FOR RURAL ELECTRIFICATION IN NEPAL
}

\author{
Rana Bahadur Thapa*, Bishnu Raj Upreti, Durga Devkota, Govind Raj Pokharel \\ Department of Rural Sociology and Development Studies, Agriculture and Forestry University, \\ Rampur, Chitwan, Nepal. \\ *Corresponding author E-mail: rbthapa830@gmail.com
}

Citation: Thapa, R.B., Upreti, B.R., Devkota, D., and Pokharel, G.R. 2020. Identifying the best decentralized renewable energy system for rural electrification in Nepal. J. Asian Rur. Stud. 4(1): 49-70

\begin{abstract}
Access to electricity is generally recognized as an important factor for economic and social development. Moreover, the world energy consumption depends on the use of limited resources like fossil fuels that induce adverse impact on the environment and society. As an alternative, renewable energies turn into crucial alternative energy ensuring sustainable energy needs and taking care of society, economy and the environment. In order to combat such issues, the United Nations has declared universal access to affordable, reliable and modern energy for by 2030. In many cases, different types of renewable energy systems are being developed to serve energy need without considering the best alternative. Thus, this paper tries to prioritize the installed Decentralized Renewable Energy (DRE) systems for rural electrification in Nepal by analyzing nineteen sustainability indicators related to four sustainability dimensions - technical, social, economic and environmental. An Analytical Hierarchy Process-Online Software (AHPOS) model is used for ranking various DRE systems. Suitable goals, criteria, sub-criteria, and alternatives are developed after reviewing pertinent literature and consultation of the experts. The results reveal that micro-hydropower is the best electrification option followed by the solar home system, solar mini-grid, and wind-solar hybrid for decentralized electrification in Nepal. Biomass is found to be the least prioritized alternative in Nepal. The outcome of the research can help the policy-makers and decision-makers in shaping energy policies, plans, and programs, and foster sustainable energy development in the country. Similarly, the relevant stakeholders will be benefited by improving their products and services in the future.
\end{abstract}

Keywords: Renewable energy; Sustainability; Analytical hierarchy process; Decentralized

\section{Introduction}

Many developing countries including Nepal will face severe energy crisis in the future (Williams et al., 2015). In addition, due to lack of energy access, increasing trend of per capita energy consumption and population growth of the world will compel serious problem to traditional energy resources like fossil fuel, forest resources etc. This situation ultimately intensify the scarcity in world energy resource and also increase environmental consequence like climate change and its direct impact can be on human, society, economy, and the environment. Ultimately, it creates an inductive environment for exploitation of renewable energy technologies; as a result, development of 
renewable energy sources is taking pace remarkably in the recent decades. Among the various renewable energy systems promoted, the policy-makers and decision-makers needs to be well aware of the technology, which is the best alternative to achieve a sustainable energy system for the country and the society. The suitability of certain technology varies place to place and country to country because it depends on multivariables affecting sustainability of the energy system. Therefore, it appeals for the need to identify the best Decentralized Renewable Energy (DRE) systems for off-grid electrification and to adapt such technologies in the Nepalese electrification context.

Sustainability in decentralized electrification is a multidisciplinary concept including technical, social, economic and environmental issues (Ilskog, 2008, Brent and Rogers, 2010, Bhattacharyya, 2012). As access to energy services is an important precondition for meeting basic needs and for developing a modern economy, smoothly functioning energy supply system is necessary for the stability of a country, its economy and exerts a significant influence on the quality of local and global environment (Mahapatra and Dasappa, 2012, Nouni, Mullick, and Kandpal, 2008). Similarly, rural electrification is a vital for improving the socio-economic conditions of the rural people to contribute economic development, promote livelihood security by providing electricity as an input for productive uses in agriculture and rural industries and that can improve the quality of life (Nouni et al., 2008).

Brundtland commission defines - "Sustainable development is development that meets the needs of the present without compromising the ability to future generations to meet their needs" (Brundtland et al., 1987). Nepal being a member state of the United Nations, is committed to this global initiatives i.e. decision made by the UN Conference on Sustainable Development held in Rio de Janeiro in June 2012 and the UN General Assembly held in September 2014 and 2015 (NPC, 2017). In case of energy sustainability, Nepal is committed to sustainable development goal-7 (SDG-7) to "ensure access to affordable, reliable, sustainable and modern energy for all" as one of 17 goals for 2030 (ESMAP, 2017).

Onat and Bayar (2010) claim that sustainable development is a complex fact depending on many variables. They refer that sustainability of electricity services (technologies) is ensured if it comply 3-A principle i.e. Accessibility, Availability and Acceptability. Barbier (1987) states that beneficiary oriented design (or grassroots participation) in any development program is known as sustainable development. Zen et al. (2016) also points out that measuring sustainability is a major challenge and a key issue for discussion on sustainable development. Similarly, developing a reliable tool to measure sustainability of energy system and being aware about the proper alternative is a prerequisite for policy-makers and decision-makers to distinguish whether they are fostering sustainable development or should be re-adjusted (Zen et al., 2016). Therefore, establishing reliable and measurable sustainability criteria and sub-criteria is important that needs to be continuously monitored. Haddad et al. (2017) highlight that assessing intended outcomes is highly relevant for energy policy-makers but it is a very complex, uncertain, multidimensional and multi-stakeholders problem. 
Indeed, identification of a suitable MCDM method, selection of proper sustainability dimension (criteria) and indicators (sub-criteria) are prerequisite in order to perform reliable decision-making process in choosing the proper technology. There are many relevant studies performed using multi-criteria analysis based on sustainability indicators for solving the problems related to decentralized and rural electrification, and some of these are summarized hereunder:

By implementing PROMETHEE II method, Haralambopoulos and Polatidis (2003) present a useful group of decision-making framework supporting multi-criteria analysis on order to rank renewable energy projects in the island of Chios, Greece. Similarly, Kumar et al. (2017) perform a comprehensive literature review of MCDM model which used in renewable energy application. Dhital et al. (2014) propose a decision-making framework for assessing four renewable energy projects (micro-hydropower, biomass, solar home system, solar pumping) with application of AHP. In order to provide energy for water pumping in Nepal, Dhital et al. (2016) perform ranking of five energy systems (diesel generator, wind power, hydropower, solar PV with battery and without battery), which reveal that hydropower followed by the solar PV are mostly preferred technologies. Kaya and Kahraman (2010) assess five renewable energy alternatives to determine the best alternative in Istanbul using fuzzy VIKOR and AHP methodology. After ranking the alternatives, the wind energy is found to be the most appropriate renewable energy in Istanbul.

Providing an integrated decision aid framework, Mamlook et al. (2001) deal with neuro-fuzzy method to solve the problems of selecting the most suitable electric power generation system alternatives for Turkey and find the solar energy as the most preferred technology. Wang et al. (2009) employ an extensive review of different stages of multi-criteria decision making for sustainable energy, i.e. selection, weighting, evaluation and final aggregation of criteria and propose four sustainability dimensions: technical, social, economic and environmental. Demirtas (2013) assesses four sustainability dimensions (technical, social, economic and environmental) as a result identified wind energy as the best renewable energy system by solving MCDM. Şengül et al. (2015), in their studies, investigate the sustainability criteria (technical, economic, social and environmental) by using MCDM technique-fuzzy TOPSIS method for ranking renewable energy supply systems in Turkey. They determine that microhydropower is the best renewable energy supply system in Turkey. By using AHP method, Sapkota, Pokharel, and Pandey (2016) execute stakeholders survey to identify most suitable sustainable energy systems in Nepal. They considered five technologies (solar PV, wind, biodiesel, nuclear and biogas). As a result, biogas is found to be the most suitable followed by the solar PV and nuclear to be the least preferred technology though the selected technologies are not in common in Nepal. Based on secondary information, Singh and Nachtnebel (2016) deploy AHP method to prioritize gridconnected hydropower development in Nepal based on selected six-goals and five alternatives. In their findings, they conclude that medium scale hydropower is most preferred. Recently, considering four sustainability criteria and 11 sub-criteria, Dhital et al. (2018) evaluate four selected alternatives (grid, micro-hydro, solar and biomass). They applied AHP method and come up with grid technology (centralized electricity) to 
be the most suitable and biomass to be the least suitable alternative energy system in Nepal.

After reviewing the literature, we can conclude that preference on technology depends on their expected and/or available services for the country and the society. Moreover, comparing different alternatives entirely rely on the expected and/or available common service from all the alternatives. Service from energy system varies according to demand and/or supply. Mainly energy services are categorized in three forms: (1) electricity (centralized and decentralized), (2) thermal (heating, cooling, drying) and (3) mechanical (agro-processing, pumping). If energy systems are compared with respect to a specific service to be acquired from all the alternatives, he/she will be able to perform comparative study more accurately. So far, the best of authors' knowledge, all the studies are carried out focusing on renewable energy in general, none of them is exclusively focused on decentralized electrification options considering a specific service (explicitly off-grid-electricity service) from all the alternatives. Therefore, this paper aims to contribute in fulfilling this gap by proposing an Analytical Hierarchy Process-Online Software (AHP-OS) as an appropriate tool for decisionmaking process in Nepalese context. Furthermore, AHP-OS method is a paperless approach that will further ensure to check the consistency ratio by the respective respondents during the survey. Consequently, the researcher may not need to modify the acquired information like in paper based survey tools.

After reviewing pertinent literature and consultation of the experts, we identify 19 indicators (sub-criteria). Then, we they are categorized in four sustainability criteria to analyze based on AHP principle. Consequently, suitable goal, criteria, sub-criteria and alternatives are placed in hierarchy structure (Figure 1). To carry out paperless survey, a separate website (Thapa, 2018) is developed to provide relevant information to potential respondents before participating in online survey that is linked to AHP-OS tool. The results shows that micro-hydropower is the most crucial decentralized electrification option followed by the solar home system and biomass is the least prioritized alternative in Nepal. This paper has been finalized after incorporating the feedbacks received from the Second Latin American Workshop on "Energy Transition Addressing Sustainable Development" held in Bogota, Colombia during 21-24 October 2019.

The main objectives of this paper are: First, to identify the best DRE systems for rural electrification in the Nepalese context and second, to help the developers and the Government of Nepal come up with appropriate solution for developing DRE system. One of the solutions for defining the best DRE system is ranking the existing energy systems by analyzing sustainability dimensions (criteria) and indicators (sub-criteria) with the help of Multi-Criteria Decision Making (MCDM) technique.

This paper has the following structure: Section-1 includes the introduction. Section-2, consists of a concise discussion of the state-of-the-art in decentralized electrification technologies in Nepal. It covers status and brief summary of each DRE systems disseminated in the country. In Section-3, models and methodology for sustainability assessment is presented that includes establishment of decision-support framework, step-to-step process of Analytical Hierarchy Process (AHP) method for decisionmaking process. Section-4 presents the results and discussion of the study in the form of 
identifying the best DRE systems for rural electrification in Nepal. And, Section-5 concludes the study specifying the main outcomes of the study, proposes limitation and some points for further research.

\section{Decentralized Electrification Technologies in Nepal}

2.1. Status of Decentralized Electrification Technologies (DRE Systems)

Considering energy ladder suggested by recent literatures, decentralized electrification is defined as "isolated mini-grids using small generators (fossil, renewable and/or hybrid) producing AC power for a local distribution grid" (Onat and Bayar, 2010, Demirtas, 2013). Based on decentralized electrification practice in Nepal, mainly four types of electrification technologies and one pre-electrification based technology are in place providing electricity services to the rural people. Summary of completed DRE Systems in Nepal is presented in the following Table 1.

The Table 1 consists of the technologies that are supported by Alternative Energy Promotion Centre (AEPC). The Government of Nepal with support from different international development partners has believed that rural electrification projects are social projects due to high investment cost and low rate of return because of low plant load factor. Micro-hydropower projects and solar home systems are well disseminated technologies whereas rest of the technologies are quite new for Nepalese context. A brief overview of the disseminated technologies is presented in the following section.

Table 1 : Summary of completed DRE systems supported by AEPC

\begin{tabular}{|l|l|c|c|c|l|}
\hline SN & \multicolumn{1}{|c|}{ Technologies } & Numbers & $\begin{array}{c}\text { Capacity } \\
\text { (kW) }\end{array}$ & $\begin{array}{c}\text { Beneficiary } \\
\text { Households }\end{array}$ & $\begin{array}{c}\text { Electrification } \\
\text { category }\end{array}$ \\
\hline 1 & Micro-hydropower & 1,805 & 31,800 & 323,115 & Electrification \\
\hline 2 & Solar mini-grid & 13 & 471 & 1,499 & Electrification \\
\hline 3 & Wind-solar hybrid & 10 & 334 & 1,099 & Electrification \\
\hline 4 & Biomass & 8 & 455.2 & 6 & Electrification \\
\hline 5 & Solar Home System** & 952,903 & 18,105 & 952,903 & Pre-electrification \\
\hline
\end{tabular}

Source: AEPC database (2018), (AEPC, 2018b), (PwC, 2016)

* 3-Institutional Gasifiers and 3-Biogas based electrification- self consumption

** Capacity of SHS calculated considering 90:10 ratio for $20 \mathrm{Wp}$ and $10 \mathrm{Wp}$ respectively

Micro-hydropower: It is a mini-grid solution working as an isolated manner with relatively low generation $(1-100 \mathrm{~kW})$, low-voltage distribution grid $(400 \mathrm{~V}$ or $11 \mathrm{kV})$ that provides electricity to a community, village or a small town (UNDP, 2014). It is one of the matured technologies in Nepal. Though electrification from hydropower was initiated during 1960s, development of decentralized hydropower projects was mainstreamed only after establishment of AEPC in 1996 (WB, 2015). Similarly, runoff river types of projects are designed considering 11-month flow exceedance to ensure designed power be available at least 92 percentage of time in a year (AEPC, 2014, AEPC, 2018a). And decentralized micro-hydropower projects are wide spread in the country especially in hilly areas covering 55 districts out of 77 districts (AEPC, 2018b). Districts in the plain area are not suitable for micro-hydropower due to lack of available head and most of the parts are covered by national grid. Micro hydropower projects are 
providing energy for lighting, running small and medium size enterprises and ensuring electricity to social services especially in the rural parts of the country.

Solar Home Systems (SHS): Solar home system is a standalone off-grid solution that provides electricity at the point of consumption (e.g. a single home/building). This consists of battery based solar energy system (UNDP, 2014). Its usable form of energy is direct beam (thermal) radiation, which can be focused to a collector. But, diffuse (thermal) radiation scattered from clouds cannot be focused, yet it can be converted to secondary form - biomass, wind energy and hydropower (Kruger, 2006). Battery based solar home systems allow storage of energy for consumptions as required for single consumer, and it does not offer the most economical solution for the rural electrification; as a result, it is considered as a pre-electrification (UNDP, 2014). The generally preferred size of such system varies from $10 \mathrm{Wp}$ to $20 \mathrm{Wp}$ though some household may also prefer bigger than $20 \mathrm{Wp}$ up to $100 \mathrm{Wp}$. In Nepal, solar PV based home systems are quite popular in serving electricity in household level appliances like lighting, radio, TV, mobile charging etc. Average solar radiation in Nepal is 4.7 $\mathrm{kWh} / \mathrm{m}^{2} /$ day with 300 sunshine days per year showing a good potential.

Solar mini-grid: Solar mini-grids are the electrical system having single generation (1$100 \mathrm{~kW})$ and supplying low-voltage electricity $(400 \mathrm{~V}$ or $11 \mathrm{kV})$ to the communities (UNDP, 2014). Electricity from the solar mini-grids is used for lighting, running small and medium enterprises and ensuring electricity to social services. This technology is being disseminated in recent years as solar home systems, which was only one technology for providing electricity to individual household before.

Wind-solar hybrid: It is also a mini-grid system with low generation (1-100 kW), lowvoltage distribution line $(400 \mathrm{~V}$ or $11 \mathrm{kV})$, and providing electricity to a community (UNDP, 2014). In the recent years, wind-solar hybrid systems are being disseminated in the country. In this technology, temporal variation of one technology is complemented by the other technology. This technology is being popular in such places where wind resource is better. It is also a mini-grid based electrical system having single generation and providing electricity to the communities, enterprises and social services.

Biomass: Biomass refers energy from plants or their products. Energy from biomass is derived from forest and agricultural products and municipal waste in the form of solid (wood, wood chip, dung etc.), liquid (vegetable oil) or gaseous (biogas) forms (Sastresa, Usón, Bribián, and Scarpellini, 2010). Biomass and bio-energy can be used to produce electricity and heat or it can be used as gaseous, liquid or solid fuel (IPCC, 2011). Electrification from biomass resources is also a new technology in Nepal though it is quite popular in other countries. It is based on either gasifier based on forest product or biogas based on energy from waste. In Nepal, the electricity produced from gasifier or biogas technology is entirely consumed by the same institution. So, till date electricity from biomass is not being used for rural electrification purpose. 


\section{Models and Methodology}

\subsection{Establishing Decision-Support Framework}

The decision-support framework for prioritizing sustainability criteria (dimension) and sub-criteria (indicators) of decentralized electrification system is outlined in Figure 1. It involves the following procedures:

1. Selection of suitable tool- Analytical Hierarchy Process-Online Software (AHPOS) as a multi-criteria decision analysis (MCDA) tool;

2. Selection of indicators for assessing sustainability of energy system;

3. Categorization of indicators in four-dimensions: technical, social, economic and environmental;

4. Integration of sustainability dimensions and indicators via a multi-criteria decision analysis (AHP method) to determine the relative and global weightage of sustainability dimensions and indicators that determine the most suitable option for the future path.

\subsection{Analytical Hierarchy Process (AHP)}

The analytical hierarchy process (AHP) is a mathematical method for analyzing complex decision problems under multiple criteria (T. L. Saaty, 1994). In this method, three basic principles- decomposition, comparative judgment and synthesis of priorities are taken into account in problem solving. In the decomposition principle, structuring of the hierarchy is performed in which the problem to be solved is kept on the top followed by criteria in the second level, sub-criteria is placed in the third level and alternative solutions are kept at the bases. At the intermediate levels, different criteria which are the basis of decision making are kept (Nain H Afgan and Carvalho, 2008).

The principle of comparative judgments stand for setting up a matrix to carry out pairwise comparisons of the relative importance of the elements in the second level with respect to the overall objective of the first level. The scale for entering judgments is given in Table 2. Additional comparison matrices are used to compare the elements of the third level with respect to the appropriate parents in the second level and so on down the hierarchy (T. L. Saaty, 1986).

The synthesis of priority principle stands for synthesizing the priorities from the second level down by multiplying local priorities by the priority of the corresponding criterion in the level above and adding them for each element in a level according to the criteria it affects. This gives the composite or global priority of that element.

One of the characteristics of the AHP is that it provides a model for decision-making, ranking and prioritizing the problem that is flexible in users-friendly manner. Comparison values can be acquired from surveys or measurement from the respondents using fundamental scales. For analyzing sustainability indicators of DRE systems for Nepal, AHP applied in the following five steps (Bhattacharyya, 2012, Nain H Afgan and Carvalho, 2008).

\section{Step 1: Problem hierarchy:}

The goal (Identifying the Best Renewable Energy Alternative for Rural Electrification in Nepal) is located at the top-level. At the second level themes/criteria are located which are further divided into sub-criteria according to the level of detail 
required. The criteria/sub-criteria is defined as a set of attributes that allow the decision makers to set preferences.

All the solution-alternatives are placed at the bottom of the hierarchy in order to make a final decision (Bhattacharyya, 2012, Nain H Afgan and Carvalho, 2008). The four dimensions/criteria that are considered to analyze sustainability indicators of installed DRE Systems for rural electrification in Nepal is: technical, social, economic, and environmental. And various 19 sub-criterion/indicators are considered within each of the four dimensions to measure/compare the sustainability of installed DRE Systems. Based on the AHP model, the hierarchical structures is shown in Figure 1.

\section{Step 2: Set of priorities for criteria, sub-criteria and alternatives:}

According to the preference of the decision makers, a numerical value shall be assigned to each criterion and alternatives. As per Saaty, the nine-scale is proposed for assigning numerical value as per Table 2 . In the case of setting priorities for sub-criteria, a paired comparisons is formulated for establishing importance of the sub-criteria with respect to a higher level (Algarín, Llanos, and Castro, 2017, Nain H Afgan and Carvalho, 2008). In case of setting priorities for alternatives, paired comparisons between the alternatives are formulated for establishing preferences of the alternatives with respect to a higher levels as per Table 2 .

Table 2: Analytic Hierarchy Measurement Scale (Nain H Afgan and Carvalho, 2008).

\begin{tabular}{|c|l|l|}
\hline $\begin{array}{l}\text { Reciprocal Measure of } \\
\text { Intensity of Importance }\end{array}$ & Definition & Explanation \\
\hline 1 & Equal importance & $\begin{array}{l}\text { Two activities contribute equally to } \\
\text { the objective activity over another }\end{array}$ \\
\hline 3 & $\begin{array}{l}\text { Moderate importance of one } \\
\text { over another }\end{array}$ & $\begin{array}{l}\text { Experience and judgment slightly } \\
\text { favor one activity over another }\end{array}$ \\
\hline 5 & Strong importance & $\begin{array}{l}\text { Experience and judgment strongly } \\
\text { favor one activity over another }\end{array}$ \\
\hline 7 & Very strong importance & $\begin{array}{l}\text { Activity is strongly favored and its } \\
\text { dominance is demonstrated in } \\
\text { practice. }\end{array}$ \\
\hline $2,4,6,8$ & $\begin{array}{l}\text { Inte evidence favoring one activity } \\
\text { over another is of the highest possible } \\
\text { order of affirmation }\end{array}$ \\
\hline Reciprocal of above & $\begin{array}{l}\text { If activity i has one of the above nonzero numbers assigned to it } \\
\text { when compared with activity j, then } \mathrm{j} \text { has the reciprocal value when } \\
\text { compared with i. }\end{array}$ \\
\hline
\end{tabular}

\section{Step 3: Formulation of pairwise questionnaires:}

Based on Saaty's nine-point scale, a pairwise comparison is formulated for alternatives with respect to sub-criteria (indicator) in order to acquire judgment from the experts. The cognitive psychologist Blumenthal (1997) wrote that: 
"Absolute judgment is the identification of the magnitude of some simple stimulus . . . whereas comparative judgment is the identification of some relation between two stimuli, both present to the observer. Absolute judgment involves the relation between a single stimulus and some information held in short-term memory, information about some former comparison stimuli or about some previously experienced measurement scale . . .. To make the judgment, a person must compare an immediate impression with impression in memory of similar stimuli."

\section{Step 4: Define global weight for criteria, sub-criteria and alternatives:}

Global weight for the criteria and sub-criteria are assumed to be equal within the group whereas global weight for the alternatives is obtained from the multiplication of the local weight $\left(\mathrm{w}_{\mathrm{i}}\right)$ by the global weight of the immediately superior criterion. The sum of the global weights of the alternatives in relation to each criterion is the mechanism to obtain the ranking the DRE alternative from a sustainability perspective and thereby identifying the best DRE System for rural electrification. The weights of each alternative, within them are computed using:

$$
A_{w}=\lambda_{\max } \times w \mathrm{~A}_{w}
$$

Where, A is the comparison matrix of size $n \times n$ for $n$ criteria. It is also called the priority matrix and $\mathrm{w}$ is the Eigenvector of size $n \times 1$, also called the priority vector, which is the weight. $K_{\max }$ is the maximum of Eigenvalue (T. L. Saaty, 1994). Eigenvector and priority vector could be obtained by solving for the principle Eigenvector. Though there are many means to solve the priority vector, an easy way to get an approximation of the priorities is to normalize the geometric means of the rows (R. W. Saaty, 1987).

\section{Step 5: Verify the consistency of the judgments:}

Finally, the consistency index is used to measure the degree of consistency of the estimation. The consistency index (CI) is calculated by:

$$
C I=\frac{\lambda_{\max }-n}{n-1}
$$

In order to verify the CI values, a comparison is made with the random consistency index (RI). This parameter is defined as an average of the CIs of the large set of matrices with random inputs Table 3 (Singh and Nachtnebel, 2016). In addition, Saaty defines the consistency ratio $(\mathrm{CR})=\mathrm{CI} / \mathrm{RI}$. If $\mathrm{CR} \leq 0.1$, the results are consistent. If $\mathrm{CR}$ $>0.1$, the data are inconsistent and the decision makers judgments needs to be reviewed.

Table 3: Random consistency index (RI) (R. W. Saaty, 1987)

\begin{tabular}{|c|c|c|c|c|c|c|c|c|c|c|}
\hline $\mathbf{N}$ & $\mathbf{1}$ & $\mathbf{2}$ & $\mathbf{3}$ & $\mathbf{4}$ & $\mathbf{5}$ & $\mathbf{6}$ & $\mathbf{7}$ & $\mathbf{8}$ & $\mathbf{9}$ & $\mathbf{1 0}$ \\
\hline RI & 0 & 0 & 0.52 & 0.89 & 1.11 & 1.25 & 1.35 & 1.40 & 1.45 & 1.49 \\
\hline
\end{tabular}

\subsection{Establishing criteria, sub-criteria and alternatives}

\subsubsection{Establishing criteria and sub-criteria}

Different kinds of literature related to problems of energy planning, implementation, evaluation, etc. used for multi-criteria decision making (MCDM) tools were reviewed in order to establish the criteria and sub-criteria. In such a way, 19 sub-criteria are 
prepared and then grouped into four categories/dimensions: technical, social, economic and environmental.

In consultation with experts from academic, private sector, public sectors and nongovernmental organizations, the final sub-criteria (indicators) are established. Then after, selected sub-criteria are clustered in four criteria. The final criteria and sub-criteria with description and reference are shown in Table 4.

Table 4: Selected indicators, their description and references

\begin{tabular}{|c|c|c|c|}
\hline 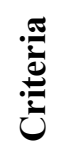 & $\begin{array}{l}\text { Sub-criteria/ } \\
\text { Indicators }\end{array}$ & Description of Indicators (Units) & References \\
\hline \multirow{6}{*}{ 苞 } & \multicolumn{3}{|c|}{$\begin{array}{l}\text { The technical sustainability of electrification focuses on the system's capacity of providing } \\
\text { the efficient and reliable energy services throughout its economic lifespan. }\end{array}$} \\
\hline & $\begin{array}{l}\text { Energy } \\
\text { availability }\end{array}$ & $\begin{array}{l}\text { It is a serviceability performance of } \\
\text { energy supply to the consumers i.e. } \\
\text { amount of electricity } \\
\text { provided/generated from the technical } \\
\text { system. }\end{array}$ & $\begin{array}{l}\text { (Ilskog, 2008, Demirtas, 2013, } \\
\text { Singh \& Nachtnebel, 2016, } \\
\text { Bhandari, Saptalena, \& Kusch, } \\
\text { 2018, Thapa, RB; Upreti, B.; } \\
\text { Devkota, D.; Pokharel, 2019 } \\
\text { Mainali \& Silveira, 2015) }\end{array}$ \\
\hline & Efficiency & $\begin{array}{l}\text { Ability of technical system to convert } \\
\text { the primary energy source to electricity. }\end{array}$ & $\begin{array}{l}\text { (Ilskog, 2008, Thapa, RB; } \\
\text { Upreti, B.; Devkota, D.; } \\
\text { Pokharel, 2019, Mainali \& } \\
\text { Silveira, 2015, Naim H. Afgan } \\
\text { \& Carvalho, 2002, AEPC, } \\
\text { 2016, UNDP, 2007) }\end{array}$ \\
\hline & Reliability & $\begin{array}{l}\text { Ability of the system to function/ } \\
\text { perform according to design conditions } \\
\text { for a specific period of time and to } \\
\text { support failures. }\end{array}$ & $\begin{array}{l}\text { (Wang et al., 2009, Demirtas, } \\
\text { 2013, Bhandari et al., 2018, } \\
\text { Thapa, RB; Upreti, B.; } \\
\text { Devkota, D.; Pokharel, 2019, } \\
\text { Mainali \& Silveira, 2015, } \\
\text { Schnitzer et al., 2014, Feron, } \\
\text { Heinrichs, \& Cordero, 2016b) }\end{array}$ \\
\hline & Plant factor & $\begin{array}{l}\text { The ratio of total energy ( } \mathrm{kWh} \text { ) used } \\
\text { divided by the total energy available in } \\
\text { certain period of time. }\end{array}$ & $\begin{array}{l}\text { (Bhandari et al., 2018, Thapa, } \\
\text { RB; Upreti, B.; Devkota, D.; } \\
\text { Pokharel, 2019, AEPC, 2016) }\end{array}$ \\
\hline & $\begin{array}{l}\text { Skill- } \\
\text { availability }\end{array}$ & $\begin{array}{l}\text { Level of skill available at the local level } \\
\text { for regular operation and management } \\
\text { of the system. It is the stage of } \\
\text { availability of spare parts/trained } \\
\text { operators and a level of know-how for } \\
\text { replacement and repair. }\end{array}$ & $\begin{array}{l}\text { (Ilskog, 2008, Thapa, RB; } \\
\text { Upreti, B.; Devkota, D.; } \\
\text { Pokharel, 2019, Algarín et al., } \\
\text { 2017, Nain H Afgan \& } \\
\text { Carvalho, 2008) }\end{array}$ \\
\hline 产 & \multicolumn{3}{|c|}{$\begin{array}{l}\text { Social sustainability focuses on the equitable distribution of benefits offered by and social } \\
\text { sustainability focuses on the equitable distribution of benefits offered by and social } \\
\text { acceptance of electrification that can be captured by enabling the technological intervention } \\
\text { in the fundamental social services. E.g. health, education, agriculture, communication and } \\
\text { information and contributing to poverty reduction by fostering income generation } \\
\text { opportunities to the locals so that everyone irrespective of any economic, social or gender } \\
\text { disparity can make the use of service provided. }\end{array}$} \\
\hline
\end{tabular}




\begin{tabular}{|c|c|c|c|}
\hline & Accessibility & $\begin{array}{l}\text { Accessibility is the proportion of } \\
\text { households in the catchment area that } \\
\text { has access to electricity. }\end{array}$ & $\begin{array}{l}\text { (Thapa, RB; Upreti, B.; } \\
\text { Devkota, D.; Pokharel, 2019, } \\
\text { Liu, Baniyounes, Rasul, } \\
\text { Amanullah, \& Khan, 2013, } \\
\text { AEPC, 2016, IAEA, 2005) }\end{array}$ \\
\hline & Affordability & $\begin{array}{l}\text { The ratio of household income spent on } \\
\text { fuels and electricity to the total } \\
\text { household income }(\%) \text {. It also refers to } \\
\text { users' perception of electricity prices. }\end{array}$ & $\begin{array}{l}\text { (Thapa, RB; Upreti, B.; } \\
\text { Devkota, D.; Pokharel, 2019, } \\
\text { Brent \& Rogers, 2010, IAEA, } \\
\text { 2005, Hong \& Abe, 2012) }\end{array}$ \\
\hline & $\begin{array}{l}\text { Social } \\
\text { acceptability }\end{array}$ & $\begin{array}{l}\text { Willingness of the community to accept } \\
\text { the implementation of the system in } \\
\text { their locality. }\end{array}$ & $\begin{array}{l}\text { (Wang et al., 2009, Demirtas, } \\
\text { 2013, Bhandari et al., 2018, } \\
\text { Thapa,RB; Upreti, B.; } \\
\text { Devkota, D.; Pokharel, 2019, } \\
\text { Hong \& Abe, 2012, Feron, } \\
\text { 2016) }\end{array}$ \\
\hline & $\begin{array}{l}\text { Gender-social } \\
\text { inclusion }\end{array}$ & $\begin{array}{l}\text { Gender and social inclusion in } \\
\text { management committee ( } \% \text { of } \\
\text { participation). }\end{array}$ & $\begin{array}{l}\text { (Singh \& Nachtnebel, 2016, } \\
\text { Thapa, RB; Upreti, B.; } \\
\text { Devkota, D.; Pokharel, 2019, } \\
\text { AEPC, 2016) }\end{array}$ \\
\hline & $\begin{array}{l}\text { Access to } \\
\text { social services } \\
\text { (Social } \\
\text { benefits) }\end{array}$ & $\begin{array}{l}\text { The capacity of the system to supply } \\
\text { energy in schools and health posts or, } \\
\text { energy access to social services [e.g. } \\
\text { health, education, information- } \\
\text { communication-technology, agriculture } \\
\text { facility] }\end{array}$ & $\begin{array}{l}\text { (Ilskog, 2008, Demirtas, 2013, } \\
\text { Bhandari et al., 2018, Thapa, } \\
\text { RB; Upreti, B.; Devkota, D.; } \\
\text { Pokharel, 2019, Algarín et al., } \\
\text { 2017, Amer \& Daim, 2011) }\end{array}$ \\
\hline & $\begin{array}{l}\text { Employment } \\
\text { generation }\end{array}$ & $\begin{array}{l}\text { Nos. of direct and indirect employment } \\
\text { generated. }\end{array}$ & $\begin{array}{l}\text { (Ilskog, 2008, Bhandari et al., } \\
\text { 2018, Thapa, RB; Upreti, B.; } \\
\text { Devkota, D.; Pokharel, 2019, } \\
\text { Brent \& Rogers, 2010, Mainali } \\
\text { \& Silveira, 2015, Algarín et al., } \\
\text { 2017, Amer \& Daim, 2011) }\end{array}$ \\
\hline$\stackrel{\mathscr{\Xi}}{\leftrightarrows}$ & $\begin{array}{l}\text { A project is eco } \\
\text { electricity servi }\end{array}$ & $\begin{array}{l}\text { mic sustainable if its revenue suffices } \\
\text { to its clients and it can manage repair }\end{array}$ & $\begin{array}{l}\text { smooth operation to provide } \\
\text { d maintenance till its lifespan. }\end{array}$ \\
\hline 5 & $\begin{array}{l}\text { Per unit } \\
\text { investment } \\
\text { cost }\end{array}$ & $\begin{array}{l}\text { It refers to the per unit initial } \\
\text { investment cost of energy system } \\
\text { (US\$/kW). Investment cost consists of } \\
\text { total expenses occurred while } \\
\text { establishing the system e.g. equipment, } \\
\text { construction, labor, infrastructure, } \\
\text { installation and commissioning costs. }\end{array}$ & $\begin{array}{l}\text { (Ilskog, 2008, Wang et al., } \\
\text { 2009, Bhandari et al., 2018, } \\
\text { Thapa, RB; Upreti, B.; } \\
\text { Devkota, D.; Pokharel, 2019, } \\
\text { Abreu Kang, da Costa Soares } \\
\text { Júnior, \& de Almeida, 2018) }\end{array}$ \\
\hline & $\begin{array}{l}\text { Operation and } \\
\text { Maintenance } \\
\text { cost }\end{array}$ & $\begin{array}{l}\text { It refers to the cost for regular operation } \\
\text { and maintenance of the energy system } \\
\text { like: salaries, stationeries, repair etc. }\end{array}$ & $\begin{array}{l}\text { (Ilskog, 2008, Wang et al., } \\
\text { 2009, Bhandari et al., 2018, } \\
\text { Thapa, RB; Upreti, B.; } \\
\text { Devkota, D.; Pokharel, 2019, } \\
\text { Mainali \& Silveira, 2015, } \\
\text { AEPC, 2016) }\end{array}$ \\
\hline
\end{tabular}




\begin{tabular}{|c|c|c|c|}
\hline & $\begin{array}{l}\text { Project Benefit } \\
\text { (Profitability) }\end{array}$ & $\begin{array}{l}\text { It is the level of income earned by the } \\
\text { system in order to operate until its life } \\
\text { span. It is measured in either form [life- } \\
\text { cycle cost, pay-back period, net present } \\
\text { value, internal rate of return, annual } \\
\text { savings]. }\end{array}$ & $\begin{array}{l}\text { (Wang et al., 2009, Demirtas, } \\
\text { 2013, Bhandari et al., 2018, } \\
\text { Thapa, RB; Upreti, B.; } \\
\text { Devkota, D.; Pokharel, 2019, } \\
\text { Brent \& Rogers, 2010, IAEA, } \\
\text { 2005, Kumar et al., 2017) }\end{array}$ \\
\hline & $\begin{array}{l}\text { Contribution } \\
\text { to users' } \\
\text { income }\end{array}$ & $\begin{array}{l}\text { Change in level of income before and } \\
\text { after energy services ( } \% \text { change). }\end{array}$ & $\begin{array}{l}\text { (Ilskog, 2008, Wang et al., } \\
\text { 2009), Bhandari et al., 2018, } \\
\text { Thapa,RB; Upreti, B.; } \\
\text { Devkota, D.; Pokharel, 2019, } \\
\text { Brent \& Rogers, 2010, } \\
\text { Schnitzer et al., 2014, AEPC, } \\
\text { 2016) }\end{array}$ \\
\hline \multirow{5}{*}{ 武 } & \multicolumn{3}{|c|}{$\begin{array}{l}\text { Environmental sustainability aims to reduce the local and global impact in the environment } \\
\text { by contributing to minimizing the negative impacts of energy solutions on the environment } \\
\text { It focuses on the adaptation of national regulation, civil society's awareness of } \\
\text { environmental issues. }\end{array}$} \\
\hline & $\begin{array}{l}\text { Environmental } \\
\text { Awareness }\end{array}$ & $\begin{array}{l}\text { Awareness is the consciousness of } \\
\text { society about the environment. It is the } \\
\text { level of awareness during the planning, } \\
\text { construction and operation phase. }\end{array}$ & $\begin{array}{l}\text { (Thapa, RB; Upreti, B.; } \\
\text { Devkota, D.; Pokharel, 2019, } \\
\text { Feron, Heinrichs, \& Cordero, } \\
\text { 2016a, Feron et al., 2016b) }\end{array}$ \\
\hline & GHG avoided & $\begin{array}{l}\text { Annual GHG emission avoided from } \\
\text { energy production and use. }(\mathrm{kg} \mathrm{CO} 2 \\
\text { eq./kWh). }\end{array}$ & $\begin{array}{l}\text { (Ilskog, 2008, Wang et al., } \\
\text { 2009, Demirtas, 2013, Singh \& } \\
\text { Nachtnebel, 2016, Bhandari et } \\
\text { al., 2018, PwC, 2016), UNDP, } \\
\text { 2007, IAEA, 2005, Mainali, } \\
\text { Pachauri, Rao, \& Silveira, } \\
\text { 2014) }\end{array}$ \\
\hline & $\begin{array}{l}\text { Loss of land } \\
\text { use }\end{array}$ & $\begin{array}{l}\text { It is the loss of land use in energy } \\
\text { generation and consumption. }\end{array}$ & $\begin{array}{l}\text { (Bhandari et al., 2018, Thapa, } \\
\text { RB; Upreti, B.; Devkota, D.; } \\
\text { Pokharel, 2019, Mainali \& } \\
\text { Silveira, 2015, Algarín et al., } \\
\text { 2017, UNDP, 2007, IAEA, } \\
\text { 2005) }\end{array}$ \\
\hline & $\begin{array}{l}\text { Household air } \\
\text { pollution } \\
\text { (HAP) } \\
\text { avoided }\end{array}$ & $\begin{array}{l}\text { Household air pollution from kerosene } \\
\text { and diesel use avoided by the plant } \\
\text { resulting in a positive impact on health } \\
\text { (eye irritation, asthma, etc.) before and } \\
\text { after the energy system. ( } \% \text { changes in } \\
\text { cases) }\end{array}$ & $\begin{array}{l}\text { (Singh \& Nachtnebel, 2016, } \\
\text { Thapa, RB; Upreti, B.; } \\
\text { Devkota, D.; Pokharel, 2019, } \\
\text { Kaya \& Kahraman, 2010, } \\
\text { Mainali et al., 2014) }\end{array}$ \\
\hline
\end{tabular}

\subsubsection{Establishing alternatives}

On the basis of existing Decentralized Renewable Energy (DRE) systems in Nepal, five types of technologies are defined for the decision making process: microhydropower, solar home system, solar mini-grid, wind-solar hybrid and biomass as shown in Hierarchy structure of ranking renewable energy alternatives in Nepal Fig. 1. 


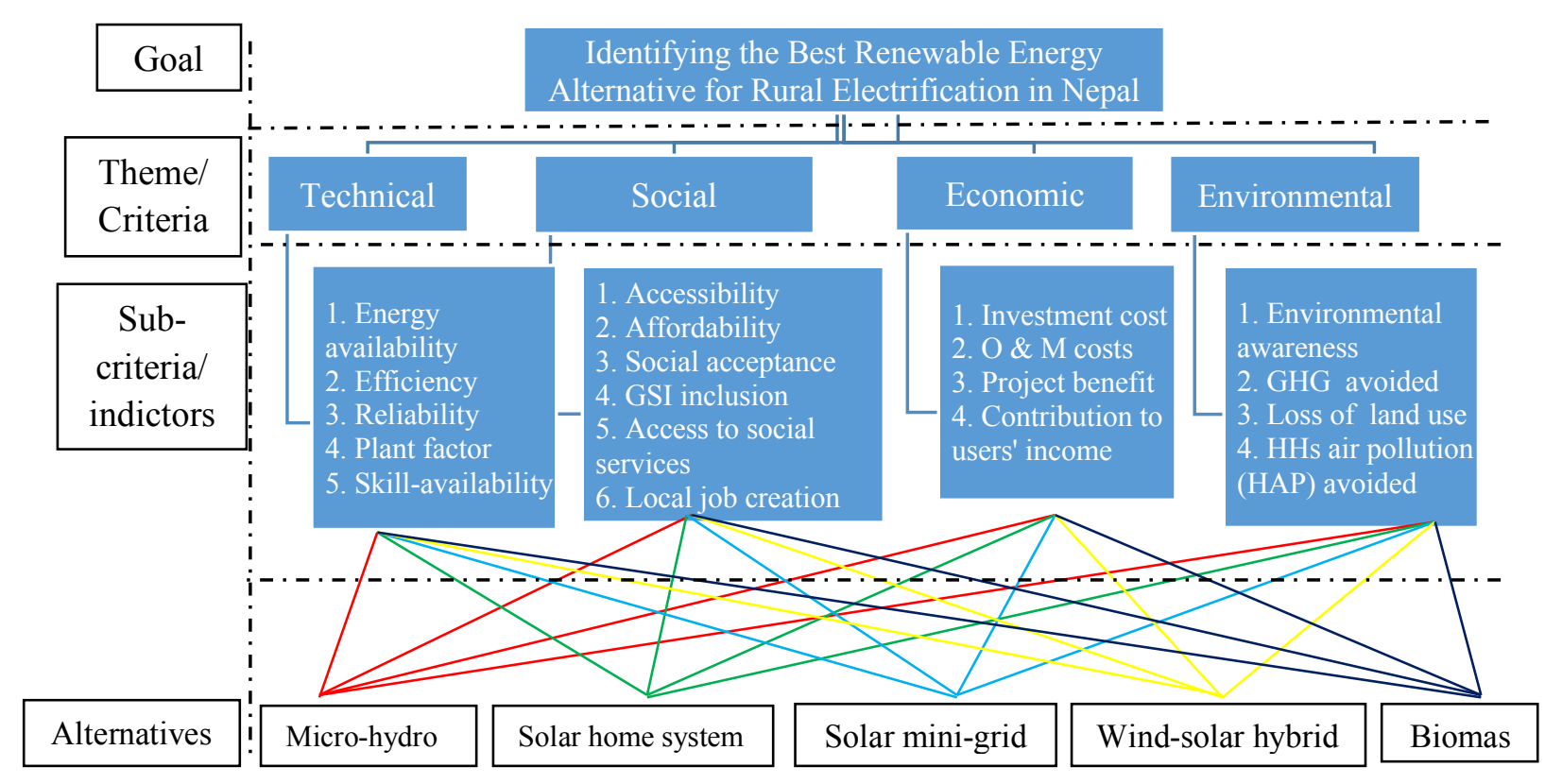

Fig. 1: Hierarchy structure of ranking renewable energy alternatives in Nepal

\subsection{Survey and Data}

Different researchers have used a various numbers of respondents (experts) to acquire their judgments. Some researchers argue that the respondents should be well aware of the criteria, sub-criteria and alternatives with pre-knowledge based on academic and/or professional experience. A systematic guide for AHP application and survey procedures are illustrated in various studies (Singh and Nachtnebel, 2016, Saaty T.L., 2008, R. W. Saaty, 1987). As per Al Garni et al. (2016), heterogeneity is essential in the decision-making process to ensure different judgments are involved and various perceptions are considered. Heterogeneity is ensured by selecting an expert panel from all sectors that are clustered in five sectors for the AHP model.

In this research, a purposive random selection method has been applied to select potential respondents. Five clusters are chosen based on their intensive involvement in the development of renewable energy system in Nepal. From each cluster/sector, about 30 potential experts have selected assuming to get response from at least half of them. Online questionnaires have been distributed to 150 experts. Distribution of selected experts in five different sectors/clusters are as per following:

- Government sector: Central, provincial, local level governmental organizations.

- Development partner/INGO: International development agencies.

- Private sector: consultants, firms, installers, manufacturers, financial institutions

- Academic sector: University professors, researchers etc. involving in energy sector.

- Developers/NGOs: Community organizations, owners, NGOs working in energy sector. 
Analytical Hierarchy Process-Online Software (AHP-OS) Tool: Business Performance Management Singapore (BPMSG) has been used to carry out surveys, compilation and analysis of the data (Goepel, 2018). All the respondents has given detailed information about purpose of survey, the criteria (dimensions), sub-criteria/indicators, and alternatives for the development of decentralized electrification from renewable energy systems in Nepal by developing a separate website (Thapa, 2018). The content of the website includes: informed consent form, detail information-alternative evaluation, stepto-step procedures for online survey and link to AHP-OS software. They have been asked to compare the importance of sub-criteria/indicators and alternatives for the installed RES in Nepal. A survey is conducted through online. Altogether 84 data sets is collected from the experts. Out of those, eight data sets are invalid because of incompleteness and/or inconsistencies. Thus, survey questionnaires received are found to be 76 , which is $90.5 \%$ of accuracy.

\section{Results and discussion}

Three-phases of the analysis have been carried out to find (i) consistency ratio, (ii) relative weights of criteria and sub-criteria, and (iii) ranking the alternatives.

In the first phase, the Consistency Ratio (CR)is considered which should generally be less than 0.2 (Soma, 2003). In this study, CR varies from 0 and 0.1 . The consistency of matrices in a pairwise comparison needs to be ensured. If the matrix is inconsistent, the respondents have been asked to make until it is achieved within the set value (i.e. $10 \%$ ), otherwise it is rejected.

In the second phase, relative local weights of alternatives with respect of each subcriterion have been analyzed with the help of pairwise comparison received from different experts. The final result of relative local weights of alternatives with respect to sub-criteria is presented in the following Table 5.

The result from Table 5 shows that though most of the cases (16 out of 19); microhydropower is the most preferential alternatives, the solar home system also got the most preference in three cases. Similarly, biomass is found to be least preferred in 11 cases and the solar home system is found to be least preferred in one case. In the rest of the cases (7 cases), wind-solar hybrid is found to be least preferred technology. In case of Algeria, solar is the most preferred technology that got most preference in 7 cases out of 13 cases, whereas hydropower is the least prioritized but it has got most preference in three cases (Haddad et al., 2017). Therefore, it can be concluded that the choice of renewable energy system depends on the selected criteria and sub-criteria of decisionmaking. The result show that micro-hydropower and solar PV provide the most benefits across the multiple sub-criteria, thus leading support for policies should encourage the increase in investment in these technologies through possible incentives. 
Table 5: Alternatives with relative local weights in relation to sub-criteria

\begin{tabular}{|l|l|c|c|c|c|c|}
\hline SN & Sub-criteria & $\begin{array}{c}\text { Micro-hydro } \\
(\%)\end{array}$ & $\begin{array}{c}\text { Solar Home } \\
\text { System (\%) }\end{array}$ & $\begin{array}{c}\text { Solar mini- } \\
\text { grid (\%) }\end{array}$ & $\begin{array}{c}\text { Wind-Solar } \\
\text { hybrid (\%) }\end{array}$ & $\begin{array}{c}\text { Biomass } \\
(\%)\end{array}$ \\
\hline 1 & $\begin{array}{l}\text { Energy } \\
\text { availability }\end{array}$ & 42.4 & 14.5 & 19.3 & 13.1 & 10.7 \\
\hline 2 & Efficiency & 40.5 & 16.4 & 19.4 & 14.8 & 9.0 \\
\hline 3 & Reliability & 40.6 & 15.8 & 18.8 & 14.3 & 10.6 \\
\hline 4 & Plant factor & 36.3 & 18.0 & 19.2 & 15.7 & 10.7 \\
\hline 5 & Skill-availability & 31.3 & 28.4 & 15.1 & 10.2 & 14.9 \\
\hline 6 & Accessibility & 25.3 & 32.0 & 15.7 & 10.4 & 16.6 \\
\hline 7 & Affordability & 22.8 & 34.9 & 14.7 & 9.9 & 17.7 \\
\hline 8 & Social acceptance & 33.0 & 26.8 & 15.7 & 10.3 & 14.3 \\
\hline 9 & $\begin{array}{l}\text { Gender and } \\
\text { social (GSI) } \\
\text { inclusion }\end{array}$ & 33.6 & 17.0 & 16.3 & 13.0 & 20.0 \\
\hline 10 & $\begin{array}{l}\text { Access to social } \\
\text { services }\end{array}$ & 39.1 & 15.6 & 18.4 & 13.4 & 13.6 \\
\hline 11 & $\begin{array}{l}\text { Local job } \\
\text { creation }\end{array}$ & 42.7 & 11.2 & 18.9 & 15.7 & 11.6 \\
\hline 12 & Investment cost & 29.7 & 24.8 & 17.7 & 13.3 & 14.6 \\
\hline 13 & $\begin{array}{l}\text { Operation and } \\
\text { management } \\
\text { costs }\end{array}$ & 26.6 & 24.6 & 20.4 & 14.7 & 13.7 \\
\hline 14 & Project Benefit & 43.3 & 12.7 & 19.8 & 15.0 & 9.2 \\
\hline 15 & $\begin{array}{l}\text { Contribution to } \\
\text { users income }\end{array}$ & 42.2 & 11.5 & 20.5 & 15.9 & 10.0 \\
\hline 16 & $\begin{array}{l}\text { Environmental } \\
\text { awareness }\end{array}$ & 33.2 & 20.8 & 18.6 & 15.5 & 11.9 \\
\hline 17 & $\begin{array}{l}\text { Greenhouse gas } \\
\text { (GHG) avoided }\end{array}$ & 36.5 & 17.5 & 19.4 & 17.2 & 9.4 \\
\hline 18 & Loss of land use & 24.0 & 25.3 & 18.8 & 16.2 & 15.7 \\
\hline 19 & $\begin{array}{l}\text { Household air } \\
\text { pollution avoided }\end{array}$ & 31.4 & 20.3 & 19.8 & 18.1 & 10.3 \\
\hline & Group Result & $\mathbf{3 4 . 4}$ & $\mathbf{2 0 . 2}$ & $\mathbf{1 8 . 4}$ & $\mathbf{1 4 . 3}$ & $\mathbf{1 2 . 6}$ \\
\hline Sour & & & & & & \\
\hline
\end{tabular}

Source: Data Analysis, 2019 
In the third phase of analysis, priority values for the alternatives have been determined. Consolidated priority value of the sustainability of renewable energy systems and their preferential ranking are presented in the following Table 6.

Table 6: Overall Priority and Ranking of Alternatives

\begin{tabular}{|l|c|c|c|c|c|}
\hline Alternatives & Minimum & Maximum & Mean & Standard Deviation & Rank \\
\hline Micro-hydropower & 0.228 & 0.433 & 0.345 & 0.067 & 1 \\
\hline Solar Home System & 0.112 & 0.349 & 0.204 & 0.069 & 2 \\
\hline Solar mini-grid & 0.147 & 0.205 & 0.182 & 0.018 & 3 \\
\hline Wind-Solar hybrid & 0.099 & 0.181 & 0.140 & 0.024 & 4 \\
\hline Biomass & 0.090 & 0.200 & 0.129 & 0.031 & 5 \\
\hline
\end{tabular}

From Table 6, it can be concluded that micro-hydropower is identified as the best DRE alternatives with the highest priority weight (0.344) and biomass is the least preferred alternatives with priority weight of 0.126 . The solar home system is found to be the second preferred alternatives (0.202) followed by solar mini-grid (0.184) and wind-solar hybrid (0.143). Micro-hydropower priority is as per expected because it is well recognized DRE option for the country and among the respondents from all the cluster. Dhital et al., (2018) in their study, have also come up with grid to be the most preferred followed by micro-hydropower, solar and biomass respectively, in which micro-hydropower is most preferred among the off-grid technologies. Whereas in case of Turkey and Algeria, hydropower is ranked to be the least preferred technology among five alternatives and wind (Turkey) and solar (Algeria) are the most preferred one. The authors claim that due to abundance wind or solar potential more importance is given to this technology and less importance is given to hydro in Turkey (Demirtas, 2013), (Haddad et al., 2017). Similarly, Lee \& Chang, (2018) presents the prioritization of renewable energy alternatives for Taiwan with hydro as the most prioritized followed by solar PV, wind, biomass and geothermal. Therefore, it can be concluded that the preference of sustainable technology vary from country to country based on resource availability and technology maturity. Nepal has good hydro potential and being well disseminated technology is able to get the first priority.

In the fourth phase of analysis, the ranking order of alternatives based on choices made by the respondents separating each clusters are identified and presented in the following Table 7. 
Table 7: Priority value and ranking of alternatives based on sectoral responses

\begin{tabular}{|l|c|c|c|c|c|c|}
\hline \multicolumn{1}{|c|}{ Alternatives $\rightarrow$} & $\begin{array}{c}\text { Micro } \\
\text { Sector } \downarrow\end{array}$ & $\begin{array}{c}\text { Solar } \\
\text { Home } \\
\text { System }\end{array}$ & $\begin{array}{c}\text { Solar } \\
\text { Mini-grid }\end{array}$ & $\begin{array}{c}\text { Wind- } \\
\text { Solar } \\
\text { hybrid }\end{array}$ & Biomass & $\begin{array}{c}\text { Standard } \\
\text { Deviation }\end{array}$ \\
\hline Government & 0.325 & 0.206 & 0.186 & 0.152 & 0.131 & 0.085 \\
\hline $\begin{array}{l}\text { Development } \\
\text { Partner and INGO }\end{array}$ & 0.323 & 0.204 & 0.177 & 0.143 & 0.143 & 0.098 \\
\hline Private & 0.313 & 0.184 & 0.156 & 0.140 & 0.157 & 0.094 \\
\hline Academia & 0.339 & 0.212 & 0.166 & 0.139 & 0.144 & 0.100 \\
\hline $\begin{array}{l}\text { NGO and } \\
\text { Developer }\end{array}$ & 0.371 & 0.203 & 0.169 & 0.111 & 0.145 & 0.115 \\
\hline
\end{tabular}

Source: Data Analysis, 2019

The Table 7 presents the ranking order of alternatives based on experts' choices by separating each clusters/sectors. The ranking of priority is represented in order with green highest value to red lowest value. The result shows that there is no significant difference in the ranking of the alternatives because top two-ranked alternatives are found to be the same in each sector. In case of biomass, private sector has ranked in third place whereas rest four sectors preferred solar mini-grid better than biomass. There are some differences in preference or ranking of the fourth and fifth alternatives. Windsolar hybrid technology is found to be the least preferred technology from the three sectors (private, academic and NGO and developer) where as other two put biomass to be the least preferred technology. The reason of this discrepancy could be due to existence of limited knowledge to compare for these two alternatives, as both technologies are in primitive stage in Nepal. In the rest of the cases, the preference is found to the same irrespective of any sector/cluster. Therefore, it can be concluded that, the preference of the technology is the same irrespective of the background of respondent.

AHP group consensus is found to be $69 \%$ which is moderate consensus according to the definition by Dr. Klaus (Goepel, 2018). It means aggregate consensus from the group members (77 respondents) is estimated to be $69 \%$ which implies that the result of global priorities are moderately homogeneous in the research. Overall consistency ratio is found to be $0.48 \%$ and individual consistency ratio is $10 \%$ or less. Therefore, the model of prioritizing the sustainability criteria and sub-criteria from the expert opinion is validated.

\section{Conclusions}

Analytical Hierarchy Process- Online Software (AHP-OS) tool, a paperless method, is an appropriate model for policy-makers and decision makers to solve uncertainties (energy decision making problems) and to adapt the best energy systems in Nepalese context. Four criteria and 19 sub-criteria of Decentralized Renewable Energy (DRE) systems in Nepal are identified. Then, five DRE systems are ranked by analyzing information received through online survey from the experts. Summary of result is mentioned in brief as follows: 
The result shows that micro-hydropower is the best electrification option $(0.344$ priority weight) followed by the solar home system (0.202), solar-mini grid (0.184), and wind-solar hybrid (0.143). Biomass $(0.126)$ is the least prioritized alternative for decentralized electrification in Nepal. The preferences on the best alternative do not significantly differ on the variation of respondents' background. However, the choice of DRE system depends on the selected criteria and sub-criteria of decision-making.

The result of the research will help the policy-makers and decision-makers in shaping the energy policies, plans and programs and foster sustainable energy development in the country. Similarly, the relevant stakeholders will be benefited to improve their product and services in the future. The limitation of the study is exclusion of institutional and political dimensions, which are also key criteria for sustainability of rural electrification. Moreover, the study is entirely relying on experts' opinion. Therefore, future quantitative research is suggested to validate the qualitative research with project specific information.

\section{Acknowledgment}

The authors would like to thank respondents for their participation in the online survey. We gratefully acknowledge "AHP-OS author: Klaus D. Goepel" for his support in allowing the use of his software and for his valuable contribution, especially in solving problems. We gratefully acknowledge Dr. Norio Kikuchi for his financial support in carrying out this research.

\section{References}

Abreu Kang, T. H., da Costa Soares Júnior, A. M., \& de Almeida, A. T. (2018). Evaluating electric power generation technologies: A multicriteria analysis based on the FITradeoff method. Energy, 165, 10-20. https://doi.org/10.1016/j.energy.2018.09.165

AEPC. (2014). Reference Micro Hydro Power Standard. Kathmandu: Alternative Energy Promotion Centre.

AEPC. (2016). Piloting sustainability monitoring for micro hydro plants. Lalitpur.

AEPC. (2018a). Guidelines for Detailed Feasibility Studies of Micro-Hydro Projects. Kathmandu: Alternative Energy Promotion Centre.

AEPC. (2018b). Progress at a Glance: A Year in Review FY 2074/75. Lalitpur.

Afgan, Naim H., \& Carvalho, M. G. (2002). Multi-criteria assessment of new and renewable energy power plants. Energy, 27(8), 739-755. https://doi.org/10.1016/S0360-5442(02)00019-1

Afgan, Nain H, \& Carvalho, M. G. (2008). Sustainability assessment of a hybrid energy system. Energy Policy, 36(8), 2903-2910.

Al Garni, H., Kassem, A., Awasthi, A., Komljenovic, D., \& Al-Haddad, K. (2016). A multicriteria decision making approach for evaluating renewable power generation sources in Saudi Arabia. Sustainable Energy Technologies and Assessments, 16, 137-150. https://doi.org/10.1016/j.seta.2016.05.006

Algarín, C. R., Llanos, A. P., \& Castro, A. O. (2017). An analytic hierarchy process based approach for evaluating renewable energy sources. International Journal of Energy Economics and Policy, 7(4), 38-47. 
Amer, M., \& Daim, T. U. (2011). Selection of renewable energy technologies for a developing county: A case of Pakistan. Energy for Sustainable Development, 15(4), 420-435. https://doi.org/10.1016/j.esd.2011.09.001

Barbier, E. B. (1987). The Concept of Sustainable Economic Development. Environmental Conservation, 14(2), 101-110. https://doi.org/10.1017/S0376892900011449

Bhandari, R., Saptalena, L. G., \& Kusch, W. (2018). Sustainability assessment of a micro hydropower plant in Nepal. Energy, Sustainability and Society, 8(3). https://doi.org/10.1186/s13705-018-0147-2

Bhattacharyya, S. C. (2012). Review of alternative methodologies for analysing off-grid electricity supply. Renewable and Sustainable Energy Reviews, 16(1), 677-694. https://doi.org/https://doi.org/10.1016/j.rser.2011.08.033

Brent, A. C., \& Rogers, D. E. (2010). Renewable rural electrification: Sustainability assessment of mini-hybrid off-grid technological systems in the African context. Renewable Energy, 35(1), 257-265. https://doi.org/10.1016/j.renene.2009.03.028

Brundtland, G. H., Khalid, M., Agnelli, S., Al-Athel, S., \& Chidzero, B. (1987). Our common future. In New York.

Çolak, M., \& Kaya, İ. (2017). Prioritization of renewable energy alternatives by using an integrated fuzzy MCDM model: A real case application for Turkey. Renewable and Sustainable Energy Reviews, 80(February), 840-853. https://doi.org/10.1016/j.rser.2017.05.194

Demirtas, O. (2013). Evaluating the best renewable energy technology for sustainable energy planning. International Journal of Energy Economics and Policy, 3(SPECIAL ISSUE), 23-33.

Dhital, R. P., Bajracharya, T. R., \& Shrestha, R. (2018). Multi-Criteria Decision Making for Sustainability of Renewable Energy System of Nepal. Journal of Energy Technologies and Policy, 8(3), 69-81.

Dhital, R. P., Parajuli, B., Bajracharya, T. R., \& Sthrestha, R. (2016). Sustainability Assessment of Rural Solar PV Water Pumping System in Nepal. (October). Retrieved from http://conference.ioe.edu.np/conf2014Papers/IOE-CONF-201443.pdf

Dhital, R. P., Pyakurel, P., Bajracharya, T. R., \& Shrestha, R. (2014). Framework for Sustainability Assessment of Renewable Energy Projects in Nepal. International Journal of the Analytic Hierarchy Process, 6(1). https://doi.org/10.13033/ijahp.v6i1.250

ESMAP. (2017). State of Electricity Access Rep ort (SEAR). Retrieved from http://esmap.org/SEAR/

Feron, S. (2016). Sustainability of off-grid photovoltaic systems for rural electrification in developing countries: A review. Sustainability (Switzerland), 8(12), 1-26. https://doi.org/10.3390/su8121326

Feron, S., Heinrichs, H., \& Cordero, R. R. (2016a). Are the rural electrification efforts in the Ecuadorian Amazon sustainable? Sustainability (Switzerland), 8(5), 1-22. https://doi.org/10.3390/su8050443

Feron, S., Heinrichs, H., \& Cordero, R. R. (2016b). Sustainability of rural electrification programs based on off-grid photovoltaic (PV) systems in Chile. Energy, Sustainability and Society, 6(1). https://doi.org/10.1186/s13705-016-0098-4 
Goepel, K. D. (2018). Implementation of an Online Software Tool for the Analytic Hierarchy Process (AHP-OS). International Journal of the Analytic Hierarchy Process, 10(3), 469-487.

Haddad, B., Liazid, A., \& Ferreira, P. (2017). A multi-criteria approach to rank renewables for the Algerian electricity system. Renewable Energy, 107, 462-472. https://doi.org/10.1016/j.renene.2017.01.035

Haralambopoulos, D. A., \& Polatidis, H. (2003). Renewable energy projects: Structuring a multi-criteria group decision-making framework. Renewable Energy, 28(6), 961-973. https://doi.org/10.1016/S0960-1481(02)00072-1

Hong, G. W., \& Abe, N. (2012). Sustainability assessment of renewable energy projects for off-grid rural electrification: The Pangan-an Island case in the Philippines. Renewable and Sustainable Energy Reviews, 16(1), 54-64. https://doi.org/10.1016/j.rser.2011.07.136

IAEA. (2005). Energy Indicators for Sustainable Development: Guidelines and Methodologies. Vienna.

Ilskog, E. (2008). Indicators for assessment of rural electrification-An approach for the comparison of apples and pears. Energy Policy, 36(7), 2665-2673. https://doi.org/10.1016/j.enpol.2008.03.023

IPCC. (2011). IPCC special report on renewable energy sources and climate change mitigation.

Kaya, T., \& Kahraman, C. (2010). Multicriteria renewable energy planning using an integrated fuzzy VIKOR \& AHP methodology: The case of Istanbul. Energy, 35(6), 2517-2527. https://doi.org/10.1016/j.energy.2010.02.051

Kruger, P. (2006). Alternative energy resources: the quest for sustainable energy. Wiley Hoboken.

Kumar, A., Sah, B., Singh, A. R., Deng, Y., He, X., Kumar, P., \& Bansal, R. C. (2017). A review of multi criteria decision making (MCDM) towards sustainable renewable energy development. Renewable and Sustainable Energy Reviews, 69(November 2016), 596-609. https://doi.org/10.1016/j.rser.2016.11.191

Lee, H. C., \& Chang, C. Ter. (2018). Comparative analysis of MCDM methods for ranking renewable energy sources in Taiwan. Renewable and Sustainable Energy Reviews, 92(May), 883-896. https://doi.org/10.1016/j.rser.2018.05.007

Liu, G., Baniyounes, A. M., Rasul, M. G., Amanullah, M. T. O., \& Khan, M. M. K. (2013). General sustainability indicator of renewable energy system based on grey relational analysis. International Journal of Energy Research, 37(14), 1928-1936.

Mahapatra, S., \& Dasappa, S. (2012). Rural electrification: Optimising the choice between decentralised renewable energy sources and grid extension. Energy for Sustainable Development, 16(2), 146-154. https://doi.org/10.1016/j.esd.2012.01.006

Mainali, B., Pachauri, S., Rao, N. D., \& Silveira, S. (2014). Assessing rural energy sustainability in developing countries. Energy for Sustainable Development, 19, $15-28$.

Mainali, B., \& Silveira, S. (2015). Using a sustainability index to assess energy technologies for rural electrification. Renewable and Sustainable Energy Reviews, 41, 1351-1365. https://doi.org/10.1016/j.rser.2014.09.018 
Mamlook, R., Akash, B. A., \& Mohsen, M. S. (2001). A neuro-fuzzy program approach for evaluating electric power generation systems. Energy, 26(6), 619-632. https://doi.org/10.1016/S0360-5442(01)00015-9

Nouni, M. R., Mullick, S. C., \& Kandpal, T. C. (2008). Providing electricity access to remote areas in India: An approach towards identifying potential areas for decentralized electricity supply. Renewable and Sustainable Energy Reviews, 12(5), 1187-1220.

NPC. (2017). National Report on the Implementation of the 2030 Agenda for Sustainable Development. Kathmandu: GoN, National Planning Commissioning.

Onat, N., \& Bayar, H. (2010). The sustainability indicators of power production systems. Renewable and Sustainable Energy Reviews, 14(9), 3108-3115. https://doi.org/10.1016/j.rser.2010.07.022

PwC. (2016). Electricity beyond the grid: Accelerating access to sustainable power for all. PwC Global Power \& Utilities, 1-24.

Saaty, R. W. (1987). The Analytical Hierarchy Process- What and Why it is Used. Mathematical Modelling, 9(3), 161-176.

Saaty, T. L. (1986). Axiomatic foundation of the analytic hierarchy process. Management Science, 32(7), 841-855.

Saaty, T. L. (1994). How to make a decision: the analytic hierarchy process. Interfaces, 24(6), 19-43.

Saaty T.L. (2008). Decision making with the analytic hierarchy process. International Journal of Services Sciences, 1(1), 83. https://doi.org/10.1504/IJSSCI.2008.017590

Sapkota, P., Pokharel, M., \& Pandey, M. (2016). Identifying the most suitable sustainable energy system for Nepal usind analytical hierarchy process. 8(2), 353371. https://doi.org/http://dx.doi.org/10.13033/ijahp.v8i2.411

Sastresa, E. L., Usón, A. A., Bribián, I. Z., \& Scarpellini, S. (2010). Local impact of renewables on employment: assessment methodology and case study. Renewable and Sustainable Energy Reviews, 14(2), 679-690.

Schnitzer, D., Deepa, S., Carvalo, J. P., Ranjit, D., Jay, A., \& Daniel, K. (2014). Microgrids for Rural Electrification: A critical review of best practices based on seven case studies Microgrids for Rural Electrification: A critical review of best $\begin{array}{llll}\text { practices. } & \text { United Nations } & \end{array}$ https://doi.org/10.13140/RG.2.1.1399.9600

Şengül, Ü., Eren, M., Shiraz, S. E., Gezder, V., \& Şengül, A. B. (2015). Fuzzy TOPSIS method for ranking renewable energy supply systems in Turkey. Renewable Energy, 75, 617-625.

Singh, R. P., \& Nachtnebel, H. P. (2016). Analytical hierarchy process (AHP) application for reinforcement of hydropower strategy in Nepal. Renewable and Sustainable Energy Reviews, 55, 43-58. https://doi.org/10.1016/j.rser.2015.10.138

Soma, K. (2003). How to involve stakeholders in fisheries management - a country case study in Trinidad and Tobago. Marine Policy, 27(1), 47-58.

Thapa, RB; Upreti, B.; Devkota, D.; Pokharel, G. (2019). Analytical Hierarchy Process (AHP) application for identifying the best renewable energy system for rural electrification in Nepal. In 2nd Latin American Workshop on Energy TransitionAddressing Sustainable Development. 
Thapa, R. B. (2018). Sustainability of Renewable Energy Systems (RES) in Nepal. Retrieved March 20, 2019, from Web Page website: https://sustainabilityres.home.blog/informed-consent-form/

UNDP. (2007). Indicators for sustainable development. United Nations Division for Sustainable Development 2007.

UNDP. (2014). Discussion Paper, Integrated sustainable rural development: renewable energy electrification and rural productivity zones.

Wang, J. J., Jing, Y. Y., Zhang, C. F., \& Zhao, J. H. (2009). Review on multi-criteria decision analysis aid in sustainable energy decision-making. Renewable and Sustainable Energy Reviews, 13(9), 2263-2278. https://doi.org/10.1016/j.rser.2009.06.021

WB. (2015). Nepal: Scaling Up Electricity Access through Mini and Micro Hydropower Applications: A strategic stock-taking and developing a future roadmap. $\quad$ Retrieved from http://documents.worldbank.org/curated/en/650931468288599171/pdf/96844REVISED-v1-Micro-Hydro-Report-0625-2015-Final.pdf

Williams, N. J., Jaramillo, P., Taneja, J., \& Ustun, T. S. (2015). Enabling private sector investment in microgrid-based rural electrification in developing countries: A review. Renewable and Sustainable Energy Reviews, 52, 1268-1281. https://doi.org/10.1016/j.rser.2015.07.153

Zen, A. C., Lima, A., Bianchi, A. L., \& Babot, L. (2016). Sustainability, Energy and Development: A Proposal of Indicators. International Journal for Infonomics, 5(1/2), 537-541. https://doi.org/10.20533/iji.1742.4712.2012.0060 